IWONA KOLASIŃSKA-PASTERCZYK

Instytut Sztuk Audiowizualnych

Uniwersytet Jagielloński w Krakowie

\title{
Filmowe reprezentacje ostatniej wieczerzy jako locus theologicus (trzy wizje biblijnej sceny)
}

\begin{abstract}
Kolasińska-Pasterczyk Iwona, Filmowe reprezentacje ostatniej wieczerzy jako locus theologicus (trzy wizje biblijnej sceny) [Film representations of the Last Supper as locus theologicus (three visions of the biblical scene)]. "Images" vol. XXX, no. 39. Poznań 2021. Adam Mickiewicz University Press. Pp. 27-45. ISSN 1731-450X. DOI 10.14746/i.2021.39.02.

The cinematic scenes of the Last Supper were treated as a challenge to visual theology. As the Last Supper, which in the films about Jesus of Nazareth (and, of course, the gospels) is the culmination (and also a turning point as an event ending Jesus `earthly activity), it is possible to see the essence of the theological message of films referring to the gospel in its presentation. The scenes of the Last Supper from three films were subjected to a comparative analysis, each of which is an individual director's vision. These are The King of Kings (1961) by Nicholas Ray, The Passion of the Christ (2004) by Mel Gibson and The Thorn of God (2015) by Óscar Parra de Carrizosa. The selection criterion was the importance given in the films to the scenes of the Last Supper and their mutually diverse representations. It has been shown how the established new transmission of visual theology modifies the meanings determined by classical theology, basically not deviating from the framework set by it.

KEYworDs: Last Supper, locus theologicus, visual theology, classical theology, cinematic scenes of the Last Supper, the gospels, The King of Kings, The Passion of the Christ, The Thorn of God, Nicholas Ray, Mel Gibson, Óscar Parra de Carrizosa
\end{abstract}

Bywa, że sztuka ,jest formą świadectwa, składanego Ewangelii” (czy to intencjonalnie, czy w formie kryptoteologicznych odniesień) [1]. To sformułowanie można odnieść zarówno do sztuki słowa (literatury pięknej), jak i sztuk wizualnych (plastycznych, fotografii, filmu, teatru, cybermediów).

Syntezę słowa i obrazu znajdujemy już w Biblii w przypowieściach Jezusa, w których przemawiał językiem obrazów, posługując się słowem. Opowiadania przypowieściowe (dłuższe formy bądź miniatury literackie) odnoszące się do nauczania o królestwie Bożym bazowały na metaforach, ale miały też strukturę sceniczną (formę dramatu o trzech scenach), konfigurację osób opartą z reguły na zasadzie trójkąta, moment dramatycznego napięcia, sformułowanie zawierające morał (tzw. epimythion) i adres nadawczy[2]. Nakreślenie sytuacji scenicznej służyło pobudzaniu wyobraźni odbiorców nauczania, jako że opowiadania przypowieściowe bazowały na rzeczywistości życia

[1] Tak na przykład postrzegał literaturę Stanisław Celestyn Napiórkowski OFM, zob. S.C. Napiórkowski, Teologia. Zagadnienia wstępne, Katowice 1986, s. 98 .
Images

vol. XXX/no. 39

Poznań 2021

ISSN 1731-45OX 
codziennego. Przypowieści Chrystusa orzekają, za pomocą środków naturalnych, „ziemskich” (obrazowych), o Bogu[3]. Wejście do królestwa Bożego na przykład przedstawiają w obrazie zaproszenia przez „króla na ucztę weselną, którą wyprawił on swemu synowi” (Mt 22, 1-10; por. Łk 14,15-24). Ci, którzy przyjęli zaproszenie, zasiedli przy wspólnym stole (por. Mt 22,10)[4].

Szczególnym typem uczty zaproszonych opisanym w ewangeliach synoptycznych była ostatnia wieczerza. Ostatni posiłek, jaki Jezus zjadł $\mathrm{z}$ apostołami, w pewnym sensie należy traktować właśnie jako „zapowiedź uczty, do której Mesjasz zasiądzie ze swymi uczniami w królestwie niebieskim (por. Mt 8,11; Łk 14,15). Posiłek ten nie miał być jedynie symbolem czy obrazem przyszłej uczty, ale jej rzeczywistą antycypacją. Wynika to wyraźnie ze słów użytych w 1 Kor 10,16. Według nich wierni, którzy otrzymują chleb i kielich, uczestniczą w Ciele i Krwi Jezusa"[5].

Tak jak w przypowieściach samo słowo było niewystarczające i dla ukazania wejścia do królestwa Bożego Jezus posłużył się obrazem uczty weselnej, tak współcześnie nowym wyzwaniem dla refleksji teologicznej jest prymat obrazu nad słowem w kulturze wizualnej. Stąd, obok klasycznej teologii, jest miejsce dla nowej dyscypliny teologicznej, jaką jest teologia wizualna (pisał o niej Witold Kawecki CSsR), która „Z jednej strony jest ogólną refleksją nad całą przestrzenią ikonosfery, $\mathrm{z}$ drugiej interpretacją tych dzieł, które w sposób bezpośredni dotyczą kwestii religijnych i tematów chrześcijańskich bądź też w sposób ukryty je przedstawiają"[6]. Sztukę w ogólności, zwłaszcza tę stanowiącą syntezę obrazu i słowa, i nie wyłącznie sztukę stricte sakralną, można traktować nie tylko jako inspirującą do poszukiwania w niej elementów teologicznych i kryptoteologicznych, ale i jako inne źródło teologicznego poznania.

W czasach współczesnych zakres topiki teologicznej ulega nieustannemu poszerzeniu, wzrasta liczba „loci” (czyli miejsc) traktowanych przez metodologię teologiczną jako „teologiczne” w przestrzeniach, które dotychczas za takowe nie uchodziły[7]. Pojęcie „miejsce teologiczne” (locus theologicus) oznacza „źródło, z którego teologia czerpie argumenty do przedkładania swojej nauki (locus theologicus sedes argumentationis theologicae) i odgrywa ważną rolę w procesach konstytutywnych dla poznania teologicznego" [8]. Pojęcie loci theologici zostało ukute w XVI wieku w ramach teologii protestanckiej i oznaczało

[3] H. Weder, Gleichnisse Jesu als Metafern, 118, 184-186, za: J. Czerski, op.cit., s. 147.

[4] Za: ibidem, s. 168-169.

[5] Za: Słownik wiedzy biblijnej, red. B.M. Metzger, M.D. Coogan, Warszawa 1997, s. 797.

[6] Zob. W. Kawecki CSsR, Teologia piękna. Poszukiwanie locus theologicus w kulturze współczesnej, Poznań 2013, s. 114.
[7] Za: ibidem, s. 122.

[8] Za: K. Kranicki, Ks. Janusz St. Pasierb jako miejsce teologiczne. Szkic o tomiku „Doświadczenie ziemi”, „Kieleckie Studia Teologiczne” 2011, vol. 10, s. 215. Autor powołuje się na teksty: J. Buxakowski, Objawienie $i$ wiara, Pelplin 1997, s. 79 i H. Vorgrimler, Nowy leksykon teologiczny. Wiara - objawienie - dogmat, Warszawa 2005, s. 173. 
główne artykuły wiary uporządkowane według ich treści. W teologii katolickiej oznacza źródła poznania teologicznego[9].

Pierwsze uporządkowanie loci, nawiązujące do Topiki Arystotelesa, zaproponował Melchior Cano, hiszpański przedstawiciel scholastyki czasów soboru trydenckiego, dominikanin, profesor teologii na uniwersytecie w Salamance, w wydanym pośmiertnie dziele De locis theologicis (Salamancae 1563), gdzie uporządkował je według kryterium powagi stojącego za nimi autorytetu - spośród dziesięciu, siedem opartych było na Boskim autorytecie (tak zwane miejsca „własne” teologii), z których dwa, tj. Pismo Święte i Tradycja Apostolska, to źródła apodyktyczne, ponieważ zawierają zdania objawione; trzy dalsze: Kościół katolicki, sobory powszechne i Kościół rzymski (Stolica Apostolska), mają również charakter apodyktyczny, choć są tylko deklaratywne, kolejne dwa to powaga ojców Kościoła oraz teologów i kanonistów, a kwalifikowane są jako prawdopodobne. Trzy pozostałe to źródła "pomocnicze" teologii, wtórne i zewnętrzne, bo oparte na autorytecie wyłącznie ludzkim. Mieszczą się w tej kategorii powaga filozofów i jurystów oraz świadectwo ludzkiej historii[10].

W ujęciach współczesnych zakres pojęcia locus theologicus uległ modyfikacji i rozszerzeniu. Stanisław C. Napiórkowski OFM wyróżnia następujące kategorie źródeł teologicznych: 1) natchnione i główne (to Pismo Święte), 2) nienatchnione - podstawowe i zobiektywizowane (w tym między innymi sztuka sakralna i literatura piękna - jako pomnik Tradycji), 3) nienatchnione - pomocnicze i zobiektywizowane (wśród nich między innymi sztuka jako źródło inspiracji teologicznej i instrument pomocniczy przekazu dla kerygmatyków) oraz 4) nienatchnione - pomocnicze i niezobiektywizowane (między innymi człowiek)[11].

Każda z tych koncepcji uwzględnia, poza Pismem Świętym jako głównym autorytetem poznania teologicznego, także źródła pomocnicze: Melchior Cano dostrzegł wartość teologiczną tego, co historyczne, Stanisław C. Napiórkowski OFM uwzględnił sztukę i człowieka jako źródło inspiracji teologicznej, a ks. Czesław S. Bartnik - „świat wewnętrzny osoby ludzkiej"[12]. Locus theologicus to inaczej źródło, poprzez które zostaje przybliżona jakaś prawda Boża zawarta już w Piśmie Świętym lub Tradycji (będących źródłami prawd objawionych). Może być nim sztuka w szerokim pojęciu tego słowa (wszelkie wytwory kultury wizualnej) bądź w zawężonym - twórczość artysty (pisarza, malarza czy filmowca), dzieło (plastyczne, teatralne czy filmowe) bądź, jak w przypadku ostatniej wieczerzy - opisana lub zwizualizowana scena o fundamentalnym znaczeniu.

[9] Za: K. Rahner, H. Vorgrimler, Mały słownik teologiczny, przeł. T. Mieszkowski, P. Pachciarek, Warszawa 1996, s. 248.

[10] Zob. K. Kranicki, op.cit., s. 216.
[11] Za: S.C. Napiórkowski OFM, Jak uprawiać teologię, Wrocław 1996, s. 38.

[12] Cz.S. Bartnik, Kościół Jezusa Chrystusa, Wrocław 1982, s. 357-359 (omawia loci theologici), za: W. Kawecki, op.cit., s. 122. 
Sensy implikowane przez ostatnią wieczerzę, opisaną w ewangeliach synoptycznych, zostały sformułowane w ramach teologii klasycznej, filmowe sceny ukazujące to wydarzenie są więc wyzwaniem dla teologii wizualnej. Ostatnia wieczerza w filmach o Jezusie z Nazaretu stanowi punkt kulminacyjny i zarazem zwrotny, jako że jest wydarzeniem kończącym ziemską działalność Jezusa, antycypującym złożenie dobrowolnej ofiary z życia.

Z punktu widzenia teologii klasycznej ostatnia wieczerza odsyła do kilku zakresów znaczeniowych: ma rys paschalny (łączyła się z życiem religijnym Izraela, choć zyskała cechy nowej Paschy), charakter eschatologiczny (była znakiem, który realizuje i wskazuje na dokonanie się zbawczych obietnic Bożych), zgromadzeniem Dwunastu (inicjującym nową wspólnotę odpowiedzialną za przyszłe królestwo Boże i oznaczającym akt ustanowienia przez Jezusa nowej religii oraz utworzenia Kościoła), wydarzeniem zbawczym (w Eucharystii aktualizuje się zbawcza ofiara Jezusa, a Jego Osoba została mistycznie złożona w Ofierze Nowego Przymierza), nową misją ustanowioną słowami: „To czyńcie na moją pamiątkę!” (tzn. testamentem pozostawionym spadkobiercom-uczniom zawierającym nakaz powtarzania odnowionej Paschy poprzez ryt chleba i wina, czyli utrwalenie celebracji eucharystycznej w przyszłych pokoleniach)[13]. To, co zostało ustanowione w centralnym momencie wieczernika (przez Eucharystię), pozostaje w ścisłym związku z tym, co się wydarzyło na Golgocie - podczas męki i wraz ze zbawczą śmiercią Chrystusa.

Ostatnia wieczerza w filmie - kryteria porównawcze
Na podstawie opisów przebiegu ostatniej wieczerzy w ewangeliach synoptycznych (Mt 26,17-35, Mk 14,12-25, Łk 22,7-38) oraz w Pierwszym Liście do Koryntian św. Pawła (1 Kor 11,17-34) wskazać można na trzy wielkie tematy przez nią ewokowane: 1) dynamiczny dramatyczna zapowiedź zdrady Judasza, 2) mistyczny - ustanowienie sakramentu Eucharystii i 3) nostalgiczny - zabarwione smutkiem pożegnanie Jezusa $\mathrm{z}$ apostołami, których pozostało przy stole jedenastu. Filmowe reprezentacje przebiegu ostatniej wieczerzy, śladem biblijnych opisów i dzieł sztuki malarskiej, wskazują zwykle na uprzywilejowanie jednego $z$ tych trzech głównych tematów.

W sztuce malarskiej wyraźnie preferowane były dwa spośród nich, tj. zobrazowanie objawienia przez Jezusa apostołom faktu, że jeden $\mathrm{z}$ nich go wyda ( $\mathrm{z}$ położeniem akcentu na reakcje uczniów poruszonych tym, co usłyszeli) oraz ofiarowanie swojego Ciała i Krwi pod postacią chleba i wina, czyli moment ustanowienia Eucharystii inicjujący jej powtórzenie w katolickiej liturgii mszalnej. Znacznie rzadziej wizualizowany był trzeci $\mathrm{z}$ aspektów ostatniej wieczerzy, tj. zaakcentowanie smutku w gronie pozostałych po odejściu Judasza jedenastu oraz znaków wskazujących na zbliżającą się Mękę i koniec ziemskiego

[13] Zrekonstruowane za: A. Nowicki, Ostatnia Wieczerza Eucharystia - Kościół, Wrocław 1996, s. 3-30. 
życia Jezusa. Ten trzeci temat ma swoje źródło w Ewangelii Jana (J 13,33) w słowach wypowiedzianych przez Jezusa: „Dzieci, jeszcze krótko jestem $z$ wami. Będziecie mnie szukać, ale [...] dokąd Ja idę, wy pójść nie możecie". Temat zdrady został uwieczniony na obrazach przedstawiających ostatnią wieczerzę m.in. przez Giotta di Bandone na fresku z lat ok. 1303-1305, przez Leonarda da Vinci na malowidle ściennym w bazylice Santa Maria delle Grazie w Mediolanie z lat 1495-1498, przez El Greca (w 1570 roku, w technice olejnej na desce), przez Valentina de Boulogne na obrazie z lat 1625-1626 znajdującym się w Galerii Nazionale d'Arte Antica w Rzymie. Temat Eucharystii dominuje między innymi w Komunii apostołów Giusto du Ganda z 146o roku (z Urbino) czy na obrazie (olej na płótnie) Ostatnia Wieczerza Jacopa Tintoretta z lat 1592-1594. Temat trwogi wynikający ze świadomości nadchodzących zdarzeń uchwycił Nikołaj Gay na obrazie olejnym z 1863 roku. Obraz Salvadora Dalego Ostatnia Wieczerza z 1955 roku łączy symbole eucharystyczne z wymiarem ezoterycznym postaci Chrystusa.

W filmie, który jest przecież sztuką obrazu, podobnie jak w malarstwie, sens teologiczny sceny ostatniej wieczerzy bywa często zaszyfrowany w jej kompozycji ikonograficznej. Porównując przedstawienia ostatniej wieczerzy w sztuce filmowej (na przykładzie dzieł stanowiących kanon opowieści o Jezusie), trzeba wziąć pod uwagę następujące czynniki:

1) stopień rozbudowania sceny i sposób wpisania jej w film;

2) relację, jaka tworzy się pomiędzy Gospodarzem a uczestnikami wieczerzy;

3) przypisanie priorytetowych funkcji konkretnym apostołom przez rozmieszczenie ich przy stole;

4) przestrzenną kompozycję sceny z uwzględnieniem dominant (na przykład kluczowych motywów ikonograficznych);

5) wyznaczniki ikonosfery, składowe mise en scéne (rodzaj i wystrój izby, nakrycie stołu, obecność pokarmów-symboli przeznaczonych na ucztę);

6) sposób ujmowania zgromadzonych przez kamerę (typ uprzywilejowanych ujęć, znaczenie sąsiedztwa, mimiki i gestów postaci, sposób ich oświetlenia);

7) przebieg ustanowienia Eucharystii;

8) zgodność z jedną z Ewangelii bądź inspirację różnymi źródłami, będącą podstawą kompilacji;

9) uprzywilejowanie jednego z trzech wielkich tematów jako pochodną przedstawienia ostatniej wieczerzy bądź odwołanie do wszystkich trzech;

10) sensy teologiczne ewokowane przez dany typ przedstawienia sceny ostatniej uczty Jezusa przed Męką w odniesieniu do teologicznego przesłania filmu/ów;

11) składowe retoryki służącej ewokacji wzniosłości;

12) sensy dziedziczone bądź dodane czy naddane lub zubożone względem tekstów ewangelicznych. 
Rozwidlenie Ypsilonu: Król Królów

(The King of Kings),

USA MGM 1961,

Nicholas Ray, 168

(w roli Jezusa Jeffrey

Hunter)
Scena ostatniej wieczerzy trwa w filmie 5' 45”' (od 38:08 do 43:53) i urywa się gwałtownie w momencie, gdy kielich $\mathrm{z}$ winem (Krwią Jezusa) trafia do apostoła Piotra. W następnym ujęciu jest pokazany Judasz Iskariota przed bramą domu arcykapłana Kajfasza, a komentarz z offu informuje: „I tak Judasz Iskariota wydał Jezusa w ręce arcykapłanów i żołnierzy". Taki zabieg uwypuklenia i w samej scenie uczty, i tuż po niej zdrady Judasza wiąże się z interpretacją postaci Judasza w filmie jako członka rewolucyjnej grupy żydowskiej, dla której Jezus stał się pionkiem w politycznych rozgrywkach.

Wieczerza jest ostatnim spotkaniem w gronie dwunastu apostołów (informuje o tym komentarz: „Po raz ostatni stanął pośród apostołów. Zebrał ich wszystkich dwunastu”). Gospodarz - Jezus znajduje się pośród nich, ale i w centralnym miejscu kompozycji przestrzennej - w punkcie rozwidlenia Ypsilonu, znaku graficznego wyznaczonego przez układ stołów. Izraelska uczta paschalna miała charakter nabożeństwa liturgicznego odbywającego się według ustalonego rytuału. Przebieg wieczerzy w filmie Nicholasa Raya zaświadcza o nawiązaniu do niego, ale i odstępstwach - zaakcentowane zostały trzy błogosławieństwa pod adresem Pana, Boga wszechświata, uczynione najpierw wobec gorzkich ziół, potem „chleba, owocu ziemi” i wreszcie „owocu winnego”. Zanim Jezus przełamie chleb, by podzielić się nim z apostołami, i wzniesie kielich wina, mówiąc „Pijcie...”, daje swoim uczniom przykazanie miłości Boga i bliźniego („To jest moje przykazanie, abyście się wzajemnie miłowali, tak jak Ja was umiłowałem”) i mówi o ofierze życia w imię miłości. Gest podania zarówno kawałka chleba, jak i kielicha z winem najpierw Janowi (który zresztą zajmuje przy stole uprzywilejowane miejsce obok Jezusa) jest swego rodzaju wyróżnieniem, przypisaniem istotnej roli, wskazaniem na „pierwszeństwo”.

Ostatnia wieczerza w interpretacji Nicholasa Raya wprowadza wszystkie trzy znane tematy w kolejności: dynamiczny - związany ze zdradą Judasza, nostalgiczny - związany ze smutkiem wobec zdrady Judasza i zapowiedzią własnego odejścia, ale przełamanym radością wobec zapowiedzi ponownego przyjścia, i mistyczny - związany z ustanowieniem Eucharystii. Scena nie stanowi nawiązania do konkretnej ewangelii synoptycznej ani nawet do jednej z dwu tradycji: Marka i Mateusza lub Pawła i Łukasza. Słowa wypowiedziane przez Jezusa podczas uczty stanowią kompilację różnych źródeł. Znaczący rekwizyt sakiewka Judasza - wskazuje na nawiązanie do Ewangelii Mateusza tylko w niej jest mowa o trzydziestu srebrnikach (Mt 26,16) zapłaconych Judaszowi od razu przez władze żydowskie za współpracę. W filmie Raya Judasz ma już przy sobie sakiewkę, którą odkłada na bok i podchodzi do stołu jako ostatni, a następnie, po słowach Jezusa: „Co chcesz czynić, czyń prędzej”, odchodzi od stołu i opuszcza izbę, zabierając trzos. Słowa te z kolei wywodzą się z Ewangelii Jana (J 13,27-29 - gdzie też jest mowa o „trzymaniu pieczy nad trzosem”, tyle że w sensie opieki nad pieniędzmi apostołów), ale padają tam w kontekście spożycia przez Judasza kawałka chleba, po którym „wszedł w niego szatan”. Przykazanie 
miłości bliźniego dane w obliczu bliskiego rozstania również pochodzi z Ewangelii według św. Jana (J 15,12), podobnie jak słowa odnoszące się do „oddania życia za przyjaciół swoich” (J 15,13). Sformułowanie typu „owoc winny” też jest charakterystyczne dla Ewangelii Janowej, choć tam Jezus mówi o sobie, że jest „prawdziwym krzewem winnym” (J 15,1). W Ewangelii Jana w opisie ostatniej wieczerzy nie ma elementów eucharystycznych, a te zwieńczają scenę uczty w filmie Raya. Sformułowania, jakie zostały użyte przez Jezusa w filmie, mają więc inne źródła. Słowa ustanowienia: „To jest ciało moje” wystąpiły w opisach synoptyków Mateusza, Marka i Łukasza oraz w Pierwszym Liście do Koryntian św. Pawła, natomiast sformułowanie: „to jest moja Krew Przymierza” jest charakterystyczne dla Ewangelii Mateusza i Marka, a z kolei polecenie: „to czyńcie na moją pamiątkę!” wywodzi się z drugiej tradycji Łukasza i Pawła[14]. Ray połączył więc różne tradycje, zatem ostatnia wieczerza $\mathrm{w}$ jego interpretacji nie dziedziczy idei teologicznych wpisanych w którąś z konkretnych ewangelii.

Klucz do odczytania sensów przez nią implikowanych można odnaleźć w zakomponowaniu przestrzeni Wieczernika, a ściślej w wyglądzie stołu, przy którym zasiedli apostołowie. W ujęciu inicjującym scenę kamera ukazuje wnętrze izby z perspektywy ptasiej - jej centrum zajmują trzy zestawione ze sobą drewniane stoły $z$ ławami do siedzenia wzdłuż nich, ułożone w kształt litery Y. U szczytu stołu, usytuowany tyłem do kamery i wpisany w rozwidlenie, jakie wyznacza znak Ypsilonu, zasiada Jezus ubrany (w odróżnieniu od apostołów) w białą szatę. Układ trzech stołów nawiązujący do znaku Y nie pozostaje bez znaczenia. Według koncepcji symboliki liter Bayleya, dotyczącej zachodniego alfabetu, „Y” oznacza „trzy w jednym, skrzyżowanie, rozdroże”[15]. Laktancjusz dodał do interpretacji Ypsilonu przez pitagorejczyków (jako symbolu życia) sens chrześcijański: rozwidlenie dróg oznacza, „że te dwie drogi są drogami do nieba i do piekła, ponieważ sprawiedliwym przeznaczona jest nieśmiertelność, niesprawiedliwym zaś wieczna kara”[16]. Stół, przy którym spożywają wieczerzę apostołowie, jest swego rodzaju znakiem wskazującym na dwie możliwe drogi - tę, którą obrał Judasz, i tę, która pozostałym apostołom pozwoli zamienić smutek w radość. Odnosi się też do motywu wskazania przez Jezusa apostołom drogi, wywiedzionego z Ewangelii według św. Jana, gdzie Jezus najpierw mówi: „Znacie drogę, dokąd Ja idę” (J 14,4), a następnie: „Ja jestem drogą i prawdą, i życiem. Nikt nie przychodzi do Ojca inaczej jak tylko przeze Mnie" $(J$ 14,6). Znak „Y” jest również jednym z symbolów krzyża - to tzw. krzyż widlasty. Był on „pierwotnym znakiem symbolizującym tchnienie w wodę chrzcielną" [17]. Z czasem znak ten „przybrał postać greckiej

[14] Zob. porównanie tekstów eucharystycznych:

J. Czerski, op.cit., s. 268.

[15] J.E. Cirlot, Słownik symboli, przeł. I. Kania, Kraków 2000, s. 234.
[16] Divinarum... za: D. Forstner OSB, Świat symboliki chrześcijańskiej. Leksykon, przeł. i oprac. W. Zakrzewska, P. Pachciarek, R. Turzyński, Warszawa 2001, s. 32.

[17] Ibidem, s. 15. 
litery $\psi$ (Psi). Prawdziwe znaczenie tego znaku kryje się w aluzji do drzewa życia”[18]. Interpretuje się znak $\psi$ (Psi) jako „krzyż rozumiany przewrotnie, a mianowicie nie jako zwykły krzyż, lecz jako 'krzyż drzewa życia"' $[19]$. W filmie Raya stół w Wieczerniku jest prefiguracją śmierci Chrystusa na drzewie krzyża, przez którą obdarzył ludzi życiem Bożym. Ostatnia wieczerza jest $w$ filmie Nicholasa Raya jednym z ogniw składających się na obraz Jezusa jako „Drogi, Prawdy i Życia”[20].

Uobecnienie krwawej Ofiary: Pasja (The Passion of the Christ), USA 2004, reż. Mel Gibson (w roli Jezusa James Caviezel)
Pasja Mela Gibsona ukazuje ostatnie dwanaście godzin życia i męki Jezusa. Film otwiera scena modlitwy Jezusa w ogrodzie Oliwnym, wydarzenia będącego następstwem ostatniej wieczerzy, związanego ze zdradą Judasza, w efekcie której Jezus został pojmany. Wobec ramy, jaką stanowią modlitwa w ogrodzie Oliwnym w ekspozycji filmu oraz śmierć i zmartwychwstanie w epilogu, w Pasji Mela Gibsona ostatnia wieczerza nie została wyodrębniona jako osobna sekwencja filmowa, lecz jest przywołana $\mathrm{w}$ formie retrospekcji - ujęć wplecionych w męczeństwo Jezusa na Golgocie. Pierwsze z nich zostało przywołane, gdy poraniony Jezus już na szczycie Golgoty wznosi oczy ku niebu, na którym świetlista smuga przybiera kształt krzyża. To spojrzenie w niebo poprzedza zbliżenie na dłonie owijające w płótno chlebowe placki, po czym zawiniątko zostaje złożone na stole przed Jezusem, a apostoł Jan odsłania chleb. Przygotowanie chleba na wieczorny posiłek zostało wpisane pomiędzy dwa przedstawienia: świetlistego krzyża na niebie i odarcia przez rzymskich żołdaków Jezusa z szat. Wbijanie pierwszego gwoździa w dłoń Jezusa przybijanego do krzyża zostało powiązane z zapowiedzią przez Jezusa jego rychłej śmierci: „Przyjaciele, jeszcze krótko jestem z wami. Dokąd Ja idę, wy pójść nie możecie. Nowe przykazanie daję wam, gdy mnie już nie będzie: Miłujcie się wzajemnie, jak Ja was umiłowałem...”. Podczas wypowiadania tych słów przez Jezusa z grona apostołów zgromadzonych przy stole, choć niewidocznych w kadrze, została wyeksponowana tylko jedna postać - Jana. Obraz Jezusa przybitego do krzyża, jeszcze leżącego na ziemi, zestawiony ponownie z postacią Jana jako niemego świadka Jego męki przywołuje kolejną reminiscencję z ostatniej wieczerzy: moment, gdy Jan patrzy na Jezusa, który, wznosząc przed sobą otwarte dłonie, wypowiada znamienne słowa: „Wierzcie we mnie. Ja jestem Drogą, i Prawdą, i Życiem. Nikt nie przychodzi do Ojca inaczej, jak tylko przeze mnie". Podniesienie przez Jezusa chleba zostało $\mathrm{w}$ filmie wpisane pomiędzy dwa ujęcia: przybicia do krzyża tablicy z napisem: „Jezus Nazarejczyk, Król Żydowski” i postawienia Chrystusowego krzyża. Biorąc do ręki chleb, Jezus wypowiada słowa: „Bierzcie i jedzcie, to jest Ciało moje, które za was będzie wydane". W filmie Gibsona Jezus jedynie wypowiada te słowa nad chlebem, ale dzielenie się nim $\mathrm{z}$ apostołami już nie zostało pokazane. Nieco inaczej jest w przypadku słów wypowiedzianych nad
[18] Ibidem, s. 15.

[19] Ibidem, s. 32.
[20] Zob. I. Kolasińska, Film biblijny, [w:] Wokół kina gatunków, red. K. Loska, Kraków 2001, s. 224. 
kielichem. Spływające po nogach zawisłego na krzyżu Jezusa i samym drzewcu strugi krwi stanowią pomost przywołujący - na zasadzie skojarzenia obrazowego - ukazany w planie bliskim strumień czerwonego wina nalewanego $\mathrm{z}$ dzbana do glinianego naczynia, po czym Jezus wznosi je do ust i po napiciu się z niego zwraca się do apostołów, równocześnie przekazując naczynie Janowi.

W Pasji Gibsona epizody z ostatniej wieczerzy zostały przywołane w kontekście tego, co już się dokonało - zdrady Judasza w ogrodzie Getsemani i tego, co się dokonuje na Golgocie - męczeńskiej śmierci Jezusa na krzyżu. Stąd przeniesienie akcentu z posiłku wspólnotowego na ucztę „nowej Paschy”. Sposób filmowania z dominacją planów bliskich unieważnia charakter przestrzeni (za plecami siedzących przy stole widoczna jest pusta ściana, a izba pogrążona jest w półmroku) i redukuje liczbę postaci do kluczowych osób dramatu: Jezusa siedzącego pomiędzy apostołami Piotrem (po Jego prawicy) i Janem (po lewicy), za którym siedzi Judasz (zanim go wyda), z pominięciem pozostałych uczniów niewpisywanych w ramy kadru. Zabieg unieważnienia tyczy się też realiów Paschy izraelskiej. Uczestnicy uczt paschalnych zwykle zajmowali miejsca przy stole, przyjmując pozycję leżącą, tj. kładąc się „na lewym ramieniu na dywanie lub kobiercu” [21]. Tymczasem w filmie Gibsona zarówno Jezus, jak i najbliżsi mu uczniowie zasiadają za wysokim, drewnianym stołem. Zwyczajowo uczty były przygotowywane wieczorem dnia poprzedzającego święto Paschy, zaś potrawy paschalne były nacechowane symboliką i spożywane według ustalonego rytu. $\mathrm{Na}$ potrawy uczty paschalnej składały się: chleb niekwaszony w formie placka (maca), czerwone wino, gorzkie zioła (sporządzone z dzikiej sałaty, cykorii, rzeżuchy lub gorzkiej kapusty, maczane w słonej wodzie), potrawa z owoców (jabłek, orzechów, migdałów i fig z winem oraz cynamonem), a w szczególności pieczony baranek jako potrawa główna. Po obmyciu rąk nalewano pierwszy kielich wina, a po jego wypiciu podawano do stołu baranka, a następnie inne potrawy, po czym uczta kończyła się wypiciem czwartego kielicha[22]. W filmie Gibsona stół nie został suto czy dostatnio zastawiony - znajdują się na nim jedynie chleb paschalny (maca) oraz gliniany dzban z czerwonym winem i zwykły gliniany kubek. Na uwagę zasługują dwa szczegóły - jeden chleb, który zostanie oferowany, ale niepołamany, i jeden kielich, z którego wszyscy mają pić, choć zostaje przekazany tylko Janowi. Taki szczegół, jak możliwość picia z jednego kielicha, był czymś nie do pomyślenia na ucztach izraelskich, gdzie każdy musiał mieć własny kielich[23]. Ostatnia wieczerza w filmie Gibsona nie ma formy izraelskiej uczty paschalnej, ale jest nawiązaniem do stylizacji liturgicznej obecnej już w tekstach ewangelii synoptycznych i znacznie późniejszej tradycji mszy świętej (w szczególności ceremonii udzielania Komunii Świętej).

[21] Za: J. Czerski, VI. Historia męki Chrystusa. C. Ostatnia wieczerza i ustanowienie Eucharystii, [w:] idem, op.cit., s. 266.
[22] Zob. rytuał Paschy, za: ibidem, s. 264-267. [23] Za: ibidem, s. 270. 
Wyraźne uprzywilejowanie zarówno podczas wieczerzy, jak i w całym filmie postaci Jana, uchodzącego za umiłowanego ucznia Jezusa, mogłoby wskazywać na fakt, że w przedstawieniu ostatniej wieczerzy Gibson inspirował się Ewangelią Jana, skoro Jan stale jest sytuowany w pozycji naocznego i najważniejszego świadka, z perspektywy którego wydarzenia mogłyby być relacjonowane. Tymczasem z opisu ostatniej wieczerzy w Ewangelii Jana (J 13,1-30) pochodzą w filmie jedynie: element poprzedzający ucztę, czyli obmycie uczniom nóg przez Jezusa, i fakt zdrady Judasza, przy czym zawarte w ewangelii samo wskazanie na zdrajcę i jego okoliczności (kawałek chleba podany Judaszowi na znak identyfikacji zdrajcy i odprawienie go: „Co chcesz czynić, czyń prędzej”) zostały już $\mathrm{w}$ filmie pominięte (choć pojmanie Jezusa, sąd nad nim i ukrzyżowanie stanowią jego efekt). Zapowiedź własnej śmierci oraz wspomnienie o ofierze z życia za „przyjaciół swoich” wywodzą się także z Ewangelii Jana (to J 13, 33 i J 15,13) - stanowią część Mowy Pożegnalnej. Podobnie wypowiedziane przez Jezusa podczas wieczerzy przykazania miłości bliźniego oraz wiary w Niego (który jest „Drogą, Prawdą i Życiem”) pochodzą również z Ewangelii Jana, tyle że z Mowy Pożegnalnej wygłoszonej do uczniów z okazji bliskiego rozstania (J 13,34; J 14,1-6; J 15,12-13). W opisie ostatniej wieczerzy w Ewangelii Jana brakuje elementów eucharystycznych, które znajdują się w pozostałych ewangeliach synoptycznych, a to dlatego, że dla Jana nie była to uczta paschalna. Jan gdzie indziej przytacza przypisywane Jezusowi słowa o spożywaniu Jego Ciała i piciu Jego Krwi[24] (J 6,53-56, passus: Chleb żywy, część rozdziału: Drugi pobyt świąteczny w Jerozolimie)[25]. Jest to zapowiedź ustanowienia Eucharystii, nieobecnej w opisie ostatniej wieczerzy. W swoim opisie tego wydarzenia Jan położył nacisk na zdradę Judasza, a w Mowie Pożegnalnej na okazane przez Jezusa podczas uczty świadectwo miłości. Ewangelia ta wskazuje na fakt, że „W Wielki Czwartek Jezus miał pełną świadomość faktu nadejścia momentu historycznego dopełnienia Jego misji, będącego jednocześnie momentem historycznym człowieka i ludzkości”[26].

W Pasji Mela Gibsona zwieńczeniem reminiscencji z ostatniej wieczerzy jest „komunia z Ciała i Krwi”. Wyraźnie dominuje więc temat mistyczny - ustanowienie sakramentu Eucharystii, pochodzący spoza Ewangelii wg św. Jana. Relacje o ostatniej wieczerzy, podczas której Chrystus ustanowił Eucharystię, przekazały ewangelie synoptyczne[27] Marka, Mateusza i Łukasza (stanowią jedną ze składowych

[24] Za: Stownik wiedzy biblijnej..., s. 797.

[25] Brzmi on następująco: „Rzekł do nich Jezus: 'Zaprawdę, zaprawdę, powiadam wam: Jeżeli nie będziecie spożywali Ciała Syna Człowieczego i nie będziecie pili Krwi Jego, nie będziecie mieli życia w sobie. Kto spożywa moje Ciało i pije moją Krew, ma życie wieczne, a Ja go wskrzeszę w dniu ostatecznym. Ciało moje jest prawdziwym pokarmem, a Krew moja jest prawdziwym napojem. Kto spożywa moje Ciało i Krew moją pije, trwa we Mnie, a Ja w nim"
(J 6,53-56); są to słowa wypowiedziane przez Jezusa w synagodze w Kafarnaum. Za: Pismo Święte Starego $i$ Nowego Testamentu $w$ przekładzie z języków oryginalnych, oprac. Zespół Biblistów Polskich z inicjatywy Benedyktynów Tynieckich, Poznań - Warszawa 1980, s. 1224.

[26] A. Nowicki, op.cit., s. 6.

[27] J. Czerski, VI. Historia męki Chrystusa. C. Ostatnia wieczerza i ustanowienie Eucharystii, [w:] idem, op.cit., s. 262. 
opowiadań: Mt 26,26-29, Mk 14,22-25, , Łk 22,15-20), którzy umieścili ją w kontekście zbliżającej się męki Jezusa. Biorąc pod uwagę porządek słów ustanowienia Eucharystii, najpierw odnoszących się do czynności nad chlebem, potem winem, i paralelizm słów ustanowienia: „to jest Ciało moje” - „to jest moja Krew Przymierza, która za wielu będzie wylana", można zauważyć, że Mel Gibson inspirował się w tym przypadku jedną z dwu tradycji - Marka i Mateusza (który nawiązywał do Marka), a nie Pawła (z 1 Kor) i Łukasza (w Ewangelii Łukasza został odwrócony schemat czynności - najpierw Jezus bierze kielich, a następnie chleb). Ostatnimi słowami Jezusa wypowiedzianymi podczas ostatniej wieczerzy w Pasji są wskazujące na nową misję: „To czyńcie na moją pamiątkę!”, które z kolei pochodzą z tradycji Łukasza (Łk 22,19, gdzie zostały wypowiedziane w kontekście ofiarowania chleba) i Pawła (1 Kor 11,23-25). Mel Gibson, dowolnie łącząc różne tradycje (bez zachowania konsekwencji w inspiracji jedną z ewangelii), dał w Pasji własną wizję ostatniej wieczerzy, wysuwając na plan pierwszy uobecnienie/unaocznienie Ofiary.

Kulminacyjny moment ostatniej wieczerzy - ofiarowanie przez Jezusa chleba i wina jako własnego Ciała i Krwi - jest ściśle powiązany ze złożeniem ofiary z życia na Golgocie - męką i śmiercią (dosłownością umęczonego ciała i ociekającego krwią krzyża), zgodnie $\mathrm{z}$ przeświadczeniem, że to $\mathrm{w}$ Wieczerniku zaczęła się Jego pasja[28]. Sposób relacjonowania przebiegu ostatniej wieczerzy w Pasji, tj. jako przypomnienia apostoła Jana porażonego widokiem umęczonego ciała Jezusa, wskazuje na wyraźne podporządkowanie wieczernikowej uczty ofiarnej względem ofiary krzyża. Służebna czy wręcz podrzędna rola ostatniej wieczerzy wobec nadrzędnej idei krwawej ofiary wiąże się $\mathrm{z}$ faktem utożsamienia $\mathrm{w}$ filmie tajemnicy wiary $\mathrm{z}$ bezmiarem cierpienia i sugestywnością okrutnych tortur, z wstrząsającymi obrazami umęczonego Corpus Christi, gdy tymczasem Męka była wydarzeniem unikalnym w sensie objawienia, a nie charakteru tortur (te przecież były udziałem także innych krzyżowanych na Golgocie). Wraz z przeniesieniem akcentu na namacalny, ludzki wymiar cierpienia Jezusa, Gibson chciał uwypuklić cenę, za jaką ludzkość została odkupiona[29], ale sprowadzając doświadczenie religijne do przeżycia wstrząsającego spektaklu, de facto ograniczył „to, co w tradycyjnej perspektywie religijnej najbardziej istotne - głębię przesłania Ewangelii”"[30] poprzez bazowanie na efektownym (w sensie stricte zewnętrznym) „sacrum pierwotnym, prymitywnym, barbarzyńskim, przed-ewangelicznym”[31]

[28] Por. J. Budzyński, Ł. Kubiak, Pasja. Przewodnik po filmie Mela Gibsona 100 pytań i odpowiedzi, Warszawa 2004, s. 77.

[29] Takie stanowisko prezentuje Paweł Milcarek, Wielkie spory o wielkq „Pasję", [w:] Jan Budzyński, Łukasz Kubiak, Pasja. Przewodnik po..., ibidem, s. 107. [30] Zob. M. Kempna-Pieniążek, Formuly duchowości $w$ kinie najnowszym, Katowice 2013, s. 59.
[31] Zob. S. Bobowski, Mel Gibson i religia, [w:] Sacrum w kinie dekadę później. Szkice, eseje, rozprawy, red. S.J. Konefał, M. Zelent, K. Kornacki, Gdańsk 2013, s. 64. Autor sformułował tę tezę, analizując zagadnienie ofiary w filmach Mela Gibsona poprzez pryzmat koncepcji sacrum René Girarda. 
i pozaewangelicznym (między innymi inspirowanym na przykład wizjami XIX-wiecznej mistyczki Anny Katarzyny Emmerich).

O ile w Pasji Mela Gibsona spektakularne umęczenie Jezusa na Golgocie ma licznych widzów (oprawców, tłum gapiów, cierpiących świadków ukrzyżowania jak Maryja, Matka Jezusa, i Maria Magdalena, czy milczących obserwatorów, jak apostoł Jan), to w tym kontekście zastanawiająca wydaje się ograniczona relacja pomiędzy Gospodarzem (Jezusem) a uczestnikami (Jego uczniami) w trakcie ostatniej wieczerzy i fakt, że ofiarowanie Ciała nie zostało powiązane $\mathrm{z}$ dzieleniem się chlebem $z$ apostołami, a w ofiarowaniu Krwi jedynym adresatem, który przejmuje od Jezusa kielich $\mathrm{z}$ winem, pozostaje Jan. Wobec przesunięcia akcentu na sam akt ofiarowania i na spożycie swego Ciała i Krwi z umniejszeniem znaczenia zgromadzenia Dwunastu nakaz wyrażony słowami: „To czyńcie na moją pamiątkę!” wydaje się trafiać w próżnię.

Wieczerza

upamiętniająca:

Cierń Boga (La espina de Dios), Hiszpania 2015, reż. Óscar Parra de Carrizosa (Sergio Raboso w roli Jezusa z Nazaretu)
Ze względu na rangę przypisywaną ostatniej wieczerzy w filmach na przeciwległym biegunie Pasji Mela Gibsona (z jej funkcją podrzędną, służebną wobec Ofiary krzyża) sytuuje się Cierń Boga (La espina de Dios, Hiszpania 2015) Óscara Parry de Carrizosy, w którym - mimo że sygnalizowany tytułem „cierń” sugeruje dominację aspektu pasyjnego de facto nadrzędne miejsce $\mathrm{w}$ narracji przypadło ostatniej wieczerzy, wieńczącej trzy ostatnie lata życia Jezusa-Nauczyciela, głoszącego nauki i czyniącego różne znaki/cuda na oczach swych pierwszych uczniów. W filmie Carrizosy ostatnia wieczerza to „specjalna wieczerza z Dwunastoma” - kulminacyjny moment kształtowania się „szkoły Jezusa” podczas Jego wędrówek, spotkań w scenerii oliwkowych sadów i nad jeziorem Genezaret oraz biesiadowania w domach z uczniami, prowadzenia dyskusji z nimi i nauczania poprzez przypowieści, moment zwieńczający ich wspólną drogę na ziemi. Została ukazana, jak zresztą cała wcześniejsza historia życia i niezwykłości osoby Nazarejczyka, z perspektywy Jego apostołów.

Scena ostatniej wieczerzy trwa w filmie Carrizosy blisko $22 \mathrm{mi}-$ nuty [od 1:27:06 do 1:49:04] i jest zaskakująco rozbudowaną inscenizacją motywowaną dość lapidarnymi opowieściami ewangelicznymi. Na prośbę Mistrza kolacja paschalna o specjalnym charakterze odbywa się w przeddzień Paschy - zwyczajowo obchodzonej w piątek tj. w czwartkowy wieczór[32], zatem w dzień poprzedzający Jego mękę. Zgodnie ze zwyczajem obowiązującym w Jerozolimie za czasów Jezusa uczniowie wraz z Nauczycielem zasiadają na ziemi (choć nie w pozycji wpółleżącej) przy niskich ławach przykrytych białym obrusem spływającym na podłogę wyściełaną w zagłębieniu między ławami zwiniętymi wojłokowymi derkami. W filmie Carrizosy stół przygotowany na
[32] Istnieje rozbieżność pomiędzy Ewangeliami synoptycznymi a Ewangelią Jana w określeniu dnia święta Paschy - według Jana ostatnia wieczerza odbyła się w przeddzień (tj. w czwartek) tradycyjnego święta Paschy (obchodzonego w piątek). Rozbieżność tę próbuje wyjaśnić hipoteza, iż Pesach sprawowano w dwóch terminach - faryzeusze obchodzili ją w czwartek, zaś saduceusze w piątek, za: J. Drozd, Ostatnia Wieczerza nową Paschą, Katowice 1977, s. 81. 
wieczerzę tworzą trzy ławy, których ustawienie przypomina kształtem (z perspektywy widza) odwróconą literę U. Takie ustawienie umożliwia usadzenie Jezusa i apostołów wzdłuż trzech boków stołu, przy czym najważniejszym osobom powinny przypaść miejsca u szczytu stołu po prawej i lewej stronie Gospodarza. Zanim pośród swoich uczniów zjawi się Jezus, dochodzi do sporu o pierwszeństwo, tj. zajęcie dwu honorowych miejsc po Jego lewicy i prawicy. Podczas nieobecności Mistrza i w oczekiwaniu na Jego przyjście uczniowie rozmawiają półgłosem, gromadząc się w dwu podgrupach w przeciwległych rogach izby a Judasz jako pierwszy zajmuje miejsce przy stole, siadając na uprzywilejowanym miejscu w rogu stołu po stronie prawej od wolnego miejsca pozostawionego dla Jezusa. Samowolne zajęcie miejsca przy stole zrazu budzi sprzeciw innych uczniów - Jan pyta go „dlaczego tam siada” i czyni uwagę, że o tym powinien zadecydować Nauczyciel, zaś Paweł uszczypliwie komentuje ów incydent: „Zapomniałem, że wielki Judasz nie jest taki jak reszta”. Judasz oponuje, mówiąc, że „każdy może usiąść, gdzie chce”, po czym „kłótnia o miejsca” kończy się w momencie, gdy je zajmują. Judasz zasiada w lewym górnym rogu stołu (po domniemanej prawicy Jezusa), Jan w rogu prawym (tj. po domniemanej Jego lewicy), zaś Piotr ostentacyjnie, w proteście wobec niestosownego zachowania swoich braci, wybiera miejsce odległe od tych dwu honorowych, siadając za dwoma innymi uczniami dzielącymi go od Judasza przy lewej (z perspektywy widza) krawędzi stołu i naprzeciw/ po przekątnej w stosunku do Jana. Motyw rywalizacji o pierwszeństwo $\mathrm{w}$ relacji z Jezusem nie wywodzi się wprost z żadnej z ewangelii synoptycznych - w Ewangeliach św. Mateusza i św. Marka nie ma o nim nawet wzmianki, w Ewangelii według św. Łukasza jest wprawdzie passus zatytułowany „Spór o pierwszeństwo” (Łk 22,24-30), ale odnosi się do rozstrzygnięć dylematu „Kto bowiem jest większy? Ten, kto siedzi za stołem, czy ten, kto służy?” (ŁK 22,27) [33], a nie uprzywilejowania wynikającego z zajętego miejsca przy stole; w Ewangelii według św. Jana również kwestia znaczenia miejsca przy stole nie została podjęta.

Biorąc pod uwagę okoliczności poprzedzające początek wieczerzy: wybrany termin Paschy (czwartek wieczorem), fakt, że Mistrz będzie obchodził tę uroczystość „sam ze swoimi dwunastoma apostołami”, nieobecność służącego, który mógłby im usługiwać, oczekiwanie uczniów na przybycie Jezusa, który pojawi się w sali przygotowanej do wieczerzy jako ostatni, dwa dylematy trapiące apostołów - kto im umyje stopy i czy sami powinni się usadzić przy stole, roszczenia apostołów Judasza i Jana do zajęcia honorowego miejsca obok Mistrza (pragnienie pierwszeństwa), forma stołu w kształcie litery $U$, zajęcie przez Jezusa miejsca przy stole bez naruszenia zastanego porządku rozmieszczenia postaci - to istotne szczegóły wskazują, że inspirację do przedstawienia ostatniej wieczerzy dla Carrizosy stanowiły nie ewangelie synoptyczne,

[33] Ewangelia według św. Łukasza, [w:] Pismo Święte Starego i Nowego Testamentu..., s. 1209. 
lecz Księga Urantii (Przekaz 179. Ostatnia Wieczerza)[34]. Jedyne odstępstwo, a właściwie modyfikacja, sprowadza się do rozmieszczenia apostołów względem miejsca przeznaczonego dla Jezusa. W Księdze Urantii konfiguracja postaci została określona w relacji do „prawej i lewej strony Mistrza” (Księga Urantii 179:1.5 (1937.3))[35]. W tradycji zachodniej znaczenie symboliczne przypisuje się w większym stopniu prawej niż lewej stronie - prawa łączy się zwykle z pierwszeństwem. Preferencja dla prawej strony zaznacza się w szczególności w symbolice chrześcijańskiej, w której strona lewa jest często piętnowana[36] (choć nacechowanie jest determinowane ugruntowanym zwyczajem). Na obrazie Leonarda da Vinci Ostatnia Wieczerza apostołowie zostali pogrupowani w cztery grupy po trzy osoby symetrycznie rozmieszczone względem centrum - postaci Jezusa, przy czym w najbliższej grupie po jego prawicy znaleźli się kolejno: Jan, Piotr i Judasz, postaci najistotniejsze dla rozwoju zdarzeń - „umiłowany uczeń”, „skała, na której zbuduje Kościół” i ten, który „Go wyda”. Leonardo zerwał z wcześniejszą tradycją umiejscawiania Judasza w przedstawieniach po przeciwnej stronie stołu, osobno, jako wyrzutka, poprzez izolację naznaczanego jako zdrajca. W Cierniu Boga kształt stołu przypomina odwróconą literę U, kompozycja przedstawienia i konfiguracja pierwszoplanowych postaci odpowiada zwierciadlanemu odbiciu sytuacji opisanej w Księdze Urantii.

Jezus Carrizozy jest zarazem z pozoru zwyczajnym człowiekiem - Nauczycielem pośród swoich uczniów, jak i niezwykłą osobą o boskiej godności - „obrazem Boga niewidzialnego” (Kol 1,15)[37]. $\mathrm{Na}$ budowanie wrażenia niezwykłości Jego osoby składają się drobne detale: sugestywne pominięcia niektórych szczegółów poprzez montaż, sposób ujmowania Jego twarzy i sylwetki przez kamerę, uwypuklanie znaczenia wykonywanych gestów. Podobnie nie zostało pokazane zajęcie przez Jezusa miejsca przy stole, lecz akcent przeniesiony został na uwypuklenie ciszy towarzyszącej oczekiwaniu na to, by przemówił.

[34] To księga powstała w Chicago w latach 19241955, opublikowana po raz pierwszy w języku angielskim przez Urantia Foundation w 1955 roku (pierwsze polskie wydanie książkowe pochodzi z 2010 roku). Składa się z czterech części: I - Wszechświat centralny i superwszechświaty, II - Wszechświat lokalny, III - Historia Urantii, IV - Życie i nauki Jezusa. Opisuje miejsce człowieka we wszechświecie i jego relację z Bogiem. Część IV, dotycząca życia i nauk Jezusa, ujmuje postać Jezusa i Jego nauki w kosmicznym kontekście. Opowieść o życiu Jezusa, zasadniczo zbieżna z opisem zawartym w Nowym Testamencie, została w niej poszerzona o dodatkowe szczegóły, a dwunastu apostołów przedstawiono jako ludzi z krwi i kości, obdarzonych zaletami, ale i nie pozbawionych wad. IV część księgi powstała $\mathrm{z}$ intencją wzbogacenia przekazu ewangelicznego i powrotu do pierwotnej nauki
Jezusa, tj. religii Jezusa a nie religii o Jezusie znamionującej dzisiejsze chrześcijaństwo. Zob. Księga Urantii (aut. zbior.), Urantia Foundation 2011.

[35] Księga Urantii. Przekaz 179. Ostatnia Wieczerza, s. 2, <https://www.urantia.org/pl/ksiega-urantii/przekaz-179-ostatnia-wieczerza>, dostęp: 15.12.2020. [36] Zob: Lewa i prawa strona, [w:] J. Tresidder, Stownik symboli. Ilustrowany przewodnik po tradycyjnych wyrażeniach obrazowych, znakach ikonicznych $i$ emblematach, Warszawa 2001, s. 111.

[37] Stwierdzenie apostoła św. Pawła w pierwszej części Listu do Kolosan, tzw. dogmatycznej $(1,15-2,23)$ dotyczącej bezwzględnego pierwszeństwa przed przesadnym kultem aniołów, który znamionował tendencje „pregnozy”, za: List do Kolosan, [w:] Pismo Święte Starego i Nowego Testamentu..., s. 1335. 
W kontraście do apostołów, ubranych w różnobarwne stroje, Jezus przybywa na wieczerzę w białej szacie, która jest odbierana jako „znak duchowości, świętości, prawdy i objawienia”[38], jako że biała szata jest „odzieniem mieszkańców nieba, podobieństwem do Boga, który jest "światłem okryty jak płaszczem"' (Ps 104,2) [39].

Jezus zwraca się do zgromadzonych w Wieczerniku słowami pełnymi powagi, odnoszącymi się do rychłego wypełnienia się woli Ojca, które poprzedzają zaproszenie do jedzenia i kontrastują z rubasznym nastrojem części apostołów. Wówczas Jezus ponownie przywraca podniosły nastrój, rozpoczynając rytualne czynności: biorąc do prawej ręki gliniany dzbanek $\mathrm{z}$ winem, wlewa czerwone wino do trzymanej w lewej dłoni białej czarki, wstaje i, podnosząc czarkę na wysokość barku, wypowiada słowa błogosławieństwa: „Błogosławiony jesteś, Ojcze, Boże nasz, Królu Wszechświata, który dałeś nam życie, wspierasz nas i sprawiłeś, że możemy zebrać się tu, przy tej okazji”. Kiedy wszyscy siadają ponownie przy stole, Jezus wypija pierwszy łyk wina $\mathrm{z}$ czarki, po czym bierze podobną z rąk Jana, nalewa do niej ze swojej czarki odrobinę wina i dopełnia ją winem z dzbana, przekazując ją Judaszowi, który podaje ją siedzącym za nim apostołom. Czynność ta zostanie powtórzona aż do momentu napełnienia w ten sposób wszystkich czarek i podania ich wokół stołu, aż ostatnia trafi do Judasza. Wówczas wszyscy wypijają ten pierwszy „kielich” wina. Te same rytualne gesty wykonuje Jezus w odniesieniu do płodów ziemi. Teraz Judasz podaje mu pierwszy głęboki talerz z ,gorzkimi ziołami” i warzywami (w filmie ich rolę pełni seler naciowy), a Jezus z każdego z podawanych mu talerzy wyjmuje ogonki liściowe i po umoczeniu ich w słonej wodzie wkłada ponownie do talerza, który przekazuje przez Jana dalej siedzącym apostołom. Przy pierwszej czynności umoczenia zielonego pędu w misie ze słoną wodą, Jezus wypowiada słowa błogosławieństwa: „Błogosławiony bądź, Panie, Boże nasz, Królu Wszechświata, stwórco płodów ziemi”. Po tych czynnościach Jezus sięga po niekwaszony chleb (macę), odłamuje kawałek i, podnosząc go lewą ręką na wysokość swoich oczu, mówi: „Oto gorzki chleb, który nasi przodkowie jedli w ziemi egipskiej. Ktokolwiek by był głodny, niech przyjdzie i je. Ktokolwiek byłby w potrzebie, niech odprawia Paschę. W tym roku jesteśmy w Egipcie, w przyszłym roku będziemy w ziemi Izraela. W tym roku jesteśmy niewolnikami, w przyszłym będziemy ludźmi wolnymi”.

Słowa wypowiedziane przez Jezusa na początku wieczerzy - odnoszące się do czasu powrotu do Ojca - są prawie dosłowną repliką słów z Księgi Urantii (2. Początek wieczerzy) [40], podobnie jak dalszy

[38] J. Tresidder, op.cit., s. 18.

[39] D. Forstner OSB, op.cit., s. 445.

[40] W tłumaczeniu zamieszczonym w: Księga Urantii. Przekaz 179. 2. Początek wieczerzy <https://www. urantia.org/pl/ksiega-urantii/przekaz-179-ostatnia-wieczerza>, s. 3 brzmią: „Bardzo pragnąłem spożyć $\mathrm{z}$ wami tę Paschę. Chciałem zjeść $\mathrm{z}$ wami raz jeszcze, zanim będę cierpiał, a wiedząc, że moja godzina nadeszła, uzgodniłem, aby dzisiejszego wieczora spożyć z wami tę wieczerzę, gdyż co do jutra, wszyscy jesteśmy w rękach Ojca, którego wolę przyszedłem wypełnić". 
schemat przebiegu wieczerzy: mycie stóp apostołom, ostatnie słowa do zdrajcy, ustanowienie wieczerzy upamiętniającej. Główne potrawy, jakie znalazły się na stole: płody ziemi - warzywa i gorzkie zioła, chleb paschalny (maca), czerwone wino, słona woda w misce, użyte nakrycia gliniane[41] naczynia - dzban, małe i większe czarki na wino, głębokie talerze, ustawione na ławach oliwne kaganki, wypowiedziane błogosławieństwa, wspomnienie o niewoli w Egipcie wskazują, że Carrizosa nawiązał w tym przedstawieniu do głównych elementów wieczerzy sederowej. Ucztę sederową wyróżnia szereg wyjątkowych elementów, które mają przypomnieć wyjście z Egiptu. Należą do nich: spożywanie warzyw zanurzonych w słonej wodzie - symbolu łez w niewoli, oraz gorzkich ziól, które są symbolem goryczy cierpienia Izraelitów w Egipcie, a także pokrojonych owoców, które mają przypominać biblijną glinę, używaną przez Izraelitów do wyrobu cegieł w Egipcie. Znaczącymi elementami uczty są dwa rytuały: jedzenie przełamanej macy i picie „Kielicha Odkupienia” (czerwone wino)[42].

Po kolejnym napełnieniu swojej czarki winem Jezus kieruje się w stronę Szymona Piotra (tj. do miejsca, które w Księdze Urantii zostało określone jako „najniższe miejsce na uczcie”[43]) i klęka przed nim niczym „niewolnik”, by umyć mu stopy, wprowadzając apostoła i pozostałych uczniów w zakłopotanie. Zwracając się do Piotra słowami: "Jeśli ci nie umyję stóp, nie będziesz uczestniczył ze mną w tym, co wkrótce zrealizuję" (179:3.5) podkreśla, że ze spełnieniem tej posługi wiąże się coś ważnego. Następnie zwraca się do pozostałych uczestników wieczerzy: „Ten, kto się wykąpał, nie potrzebuje się obmywać, potrzebuje tylko, aby obmyto mu stopy. Wy, którzy siedzicie ze mną tego wieczoru, jesteście czyści, choć nie wszyscy”(179:3.6)[44] (przy tych słowach patrzy wymownie na Judasza, na którego twarzy maluje się zmieszanie). W Księdze Urantii wykonanie tej posługi Jezus tłumaczy jako „przypowieść ilustrującą znaczenie nowego przykazania”, które im daje. W filmie Carrizosy Jezus wypowiada je, ponownie zasiadając przy stole: „Czy rozumiecie, co wam uczyniłem? Wy nazywacie mnie Nauczycielem i Panem i dobrze mówicie, bo nim jestem. Więc, jeśli ja Pan i Nauczyciel umyłem wam stopy, wy też powinniście myć sobie stopy jedni drugim. Nie jest większy sługa od swego pana, ani posłany od tego, który go posłał. Kto przyjmie tego, którego ja poślę, mnie przyjmie. A kto mnie przyjmie, przyjmie tego, który mnie posłał" (179:3.8)[45].

W filmie Carrizosy ustanowienie Eucharystii jest kulminacyjnym momentem wieczerzy Jezusa z apostołami - zapowiedzią Ofiary,

[41] Naczyń glinianych używały podczas Paschy rodziny biedniejsze, zob. Potrawy paschalne oraz ich symbolika, [w:] J. Czerski, op.cit., s. 265.

[42] J.J. Parsons, Worthy is the Lamb. A Messianic Passover Haggadah, s. 54, https://hebrew4christians. com/Holidays/Spring_Holidays/Pesach/H4C_Passover_Seder.pdf, Golden Valley 2015.
[43] Zob. Księga Urantii. Przekaz 179. Ostatnia Wieczerza, s. 4.

[44] Ibidem, s. 5.

[45] Cyt. za ścieżką dźwiękową filmu. Nawiązanie do Księgi Urantii, ibidem. 
ofiarowaniem Krwi i Ciała w postaci wina i chleba oraz nakazem upamiętnienia, czyli powtarzania obrzędu związanego z misją życiową Jezusa. Tym samym ostatnia wieczerza staje się „wieczerzą upamiętniającą”, w której biorą udział „ci, którzy wierzą w Syna i rozpoznają Boga"(179:5.6)[46]. Zamknięcie tej ceremonii stanowi ponowne wezwanie do wychwalania Boga, który przeprowadził lud Izraela „z niewoli do wolności, ze smutku w radość, z ciemności do światłości” powiązane z rytuałem maczania przez Jezusa w misie ze słoną wodą ogonków selera naciowego podawanych mu przez apostołów. Po tych czynnościach Jezus zdejmuje z głowy kaptur, po czym dalsze biesiadowanie przebiega już w bardziej radosnym nastroju, niczym zwyczajny posiłek w gronie bliskich sobie osób.

W stosunku do Księgi Urantii w filmie Carrizosy nieco został zmieniony porządek scen - ostatnie słowa Jezusa skierowane do zdrajcy następują po ustanowieniu wieczerzy upamiętniającej, tym samym Judasz jest jej uczestnikiem - pije wino ze wspólnego kielicha i spożywa połamany chleb (w pierwowzorze to ustanowienie dokonuje się w gronie jedenastu apostołów, po odejściu Judasza). W filmie Carrizosy Judasz pozostaje na wieczerzy prawie do jej końca. Jest nadal w gronie apostołów, gdy wszyscy, na znak dany przez Jezusa, ponownie nakrywają głowy, a Jezus intonuje świąteczny hymn dziękczynny (Psalm 118) rozpoczynający się słowami: „Alleluja. Dziękujcie Panu, bo jest dobry, bo Jego łaska trwa na wieki...”. Podniosły moment dziękczynienia podkreśla gest nakrycia głów, a po jego odśpiewaniu ich ponownego odsłonięcia. To zwieńczenie wieczerzy przez wspólne odśpiewanie Psalmu 118 rozdziela dwa dramatyczne momenty: zapowiedzi własnej śmierci („...jutro, o tej porze, już mnie tu nie będzie. Muszę wrócić do Ojca, bo przyszedł mój moment”) związanej ze zdradą („Lecz nie trzeba było, aby jeden $\mathrm{z}$ was mnie zdradził, aby mnie wydać w ręce mych wrogów”) i zwrócenia się do Judasza ze słowami: „To, co chcesz uczynić, uczyń szybko" (179:4.6), po których Judasz pośpiesznie odchodzi. Scena ostatniej wieczerzy w filmie Carrizosy kończy się specjalnym przygotowaniem Piotra - wyznaczeniem przez Jezusa Piotra na tego, który w Jego imieniu będzie głosił ewangelię Królestwa Bożego.

Rozłożenie akcentów i uwypuklenie określonych aspektów w filmowych przedstawieniach ostatniej wieczerzy decydują o ukierunkowaniu przesłania teologicznego. Przypadki inspiracji wyłącznie jedną z ewangelii, oznaczające dziedziczenie perspektywy teologicznej danego ewangelisty, są niezwykle rzadkie. Wśród tych nielicznych na plan pierwszy wysuwa się Ewangelia według św. Mateusza (1964) Piera Paola Pasoliniego, podporządkowana naczelnej idei teologicznej ewangelisty - krytyce niewierności Izraela, który odrzucił Jezusa. Z reguły każde z przedstawień ostatniej wieczerzy jest kompilacją różnych tradycji i stanowi indywidualną wizję reżyserską. Filmy Król Królów, Implikacje refleksji
teologicznej 
Pasja i Cierń Boga ilustrują kolejno trzy skrajne przypadki: usytuowania sceny $\mathrm{w}$ filmie zgodnie $\mathrm{z}$ jej pierwotnym umiejscowieniem $\mathrm{w}$ ewangeliach (większość dzieł należących do kanonu opowieści o Jezusie respektuje ten porządek), pominięcia jako osobnej sceny i przywołania reminiscencji $\mathrm{z}$ wieczerzy $\mathrm{w}$ formie wspomnień (w retrospekcjach) motywowanych wydarzeniami na Golgocie, nadania temu wydarzeniu szczególnej wagi poprzez rozbudowanie (w stosunku do ewangelicznych pierwowzorów) inscenizacji nawiązującej do Księgi Urantii powstałej z intencją wzbogacenia przekazu ewangelicznego i położenia akcentu na pierwotną naukę Jezusa.

Rys paschalny i eschatologiczny ostatniej wieczerzy najsilniej uwypuklony został w Cierniu Boga, w którym podkreślono ciągłość tradycji judeochrześcijańskiej. Wieczerza z uczniami jest $\mathrm{w}$ tym filmie ściśle powiązana z życiem Izraelitów (odwołuje się do historii narodu wybranego) i powtarza ryt paschalny, choć słowa i gesty Jezusa (zwłaszcza w kulminacyjnym momencie ustanowienia Eucharystii) nabierają nowego znaczenia. Na przeciwległym biegunie sytuuje się Pasja, w której realia Paschy izraelskiej zostały praktycznie anulowane, zaś przedstawienie jest podporządkowane stylizacji liturgicznej (na wzór późniejszego obrządku). Sceny ostatniej wieczerzy w Królu Królów i Pasji są wskazaniem na „pierwszeństwo” Jana wśród innych apostołów. W Pasji ostatnia wieczerza została ukazana przez pryzmat wspomnień Jana jako świadka wydarzeń na Golgocie i ucznia, do którego zwraca się Jezus. W Królu Królów ikonograficzny znak Ypsilonu (wyznaczony przez układ stołów) jest znakiem rozwidlenia dróg - wskazuje na dwie możliwe drogi otwierające się przed uczniami Jezusa - symbolizowaną przez „pierwszeństwo” Jana i sprzeniewierzenie się Judasza. W Cierniu Boga zaakcentowana została, powstała z inicjatywy Jezusa, wspólnota stołu (nawet w akcie ustanowienia Eucharystii biorą udział wszyscy uczniowie), co stanowi pierwszy krok w kierunku realizującego się królestwa Bożego, a uczniowie stają się pierwszymi odbiorcami zapowiedzianego przez Gospodarza daru.

W Królu Królów układ stołów w kształcie Ypsilonu, znak $\psi$ (Psi) wskazuje pośrednio na powiązanie śmierci Jezusa $\mathrm{z}$ „krzyżem drzewa życia", stanowiącym zapowiedź obdarzenia nowym życiem. W Pasji przedstawienie ostatniej wieczerzy podporządkowane zostało teologii Ofiary - intencji uobecnienia Ofiary krzyżowej Jezusa, wysunięciu na plan pierwszy cierpienia Jezusa, spychając na dalszy plan przesłanie wynikające z głoszenia królestwa Bożego. W Cierniu Boga uczta stała się wyrazem wspólnoty z Bogiem i idei, że Jezus jest pokarmem wiecznego życia, zaś Eucharystia (z prymatem kielicha eucharystycznego) symbolizuje wydarzenia pasyjne, dzieło zbawcze Chrystusa i oznacza spotkanie odkupienia.

Filmowe sceny ostatniej wieczerzy stanowią źródło pomocnicze poznania teologicznego - ustanowiony nowy przekaz teologii wizualnej modyfikuje sensy, nie odbiegające jednak zasadniczo od ram wyznaczonych przez teologię klasyczną. 
Bartnik Cz.S., Kościół Jezusa Chrystusa, Wrocław 1982

Bartnik Cz.S., Poznanie historyczne w teologii, „Roczniki Teologiczno-Kanoniczne” 1972, vol. 19, z. 2

Bobowski S., Mel Gibson i religia, [w:] Sacrum w kinie dekadę później. Szkice, eseje, rozprawy, red. S.J. Konefał, M. Zelens, K. Kornacki, Gdańsk 2013

Budzyński J., Kubiak Ł., Pasja. Przewodnik po filmie Mela Gibsona 100 pytań i odpowiedzi, Warszawa 2004

Cirlot J.E., Słownik symboli, przeł. I. Kania, Kraków 2000

Czerski J., Jezus Chrystus w świetle ewangelii synoptycznych, Opole 2000

Drozd J., Ostatnia Wieczerza nowa Pascha, Katowice 1977

Forstner D. OSB, Świat symboliki chrześcijańskiej. Leksykon, przekł. i oprac. W. Zakrzewska, P. Pachciarek, R. Turzyński, Warszawa 2001

Kawecki W. CSsR, Teologia piękna. Poszukiwanie locus theologicus w kulturze wspótczesnej, Poznań 2013

Kempna-Pieniążek M., Formuły duchowości w kinie najnowszym, Katowice 2013

Kolasińska I., Film biblijny [w:] Wokót kina gatunków, red. K. Loska, Kraków 2001

Kranicki K., Ks. Janusz St. Pasierb jako miejsce teologiczne. Szkic o tomiku „Doświadczenie ziemi”, „Kieleckie Studia Teologiczne” 2011, vol. 10

Księga Urantii, Urantia Foundation 2011

Księga Urantii. Przekaz 179. Ostatnia Wieczerza, <https://www.urantia.org/pl/ ksiega-urantii/przekaz-179-ostatnia-wieczerza>, dostęp: 15.12.2020

Napiórkowski S.C. OFM, Jak uprawiać teologię, Wrocław 1996

Napiórkowski S.C. OFM, Teologia. Zagadnienia wstępne, Katowice 1986

Nowicki A., Ostatnia Wieczerza Eucharystia - Kościół, Wrocław 1996

Parsons J.J., Worthy is the Lamb. A Messianic Passover Haggadah <https://hebrew4christians.com/Holidays/Spring_Holidays/Pesach/H4C_Passover_Seder.pdf $>$, dostęp: 16.12 .2020

Pismo Święte Starego i Nowego Testamentu $w$ przekładzie z języków oryginalnych, oprac. Zespół Biblistów Polskich z inicjatywy Benedyktynów Tynieckich, Poznań - Warszawa 1980;

Rahner K., Vorgrimler H., Mały słownik teologiczny, przeł. T. Mieszkowski, P. Pachciarek, Warszawa 1996

Siemieński M., Księga świąt i obyczajów żydowskich, Warszawa 1993

Stownik wiedzy biblijnej, red. B.M. Metzger, M.D. Coogan, Warszawa 1997

Tresidder J., Stownik symboli. Ilustrowany przewodnik po tradycyjnych wyrażeniach obrazowych, znakach ikonicznych i emblematach, Warszawa 2001

Vorgrimler H., Nowy leksykon teologiczny. Wiara - objawienie - dogmat, Warszawa 2005 